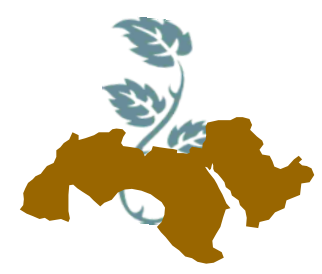

Arab Univ.

J. Agric. Sci., Ain Shams Univ., Cairo Special Issue, 26(2B), 1461-1470, 2018

\title{
IMPROVING FRUIT SET, YIELD AND FRUIT QUALITY OF KHADRAWI DATE PALM CULTIVAR
}

\author{
[107] \\ Moustafa $^{1}$ A.R.A., Abdel-Hamid ${ }^{2}$ N.A., Abd El-Hamid ${ }^{2}$ A.A., El-Sonbaty ${ }^{1}$ M.R. \\ and Abd El-Naby ${ }^{1}$ S.K.M. \\ 1- Horticultural Crops Technology Dept., National Research Center, Dokki, Giza, Egypt \\ 2- Hortic. Dept., Fac. of Agric., Ain Shams Univ., P.O. Box 68, Hadayek Shobra 11241, Cairo, \\ Egypt
}

Keywords: Date palm, Khadrawi, Fruit set, Yield, Fruit quality, Moringa extract, Garlic extract, Ascorbic acid

\section{ABSTRACT}

This experiment was carried out during 2015 and 2016 experimental seasons to investigate the effect of spraying with moringa extract at $3 \%$, garlic extract at $3 \%$ or ascorbic acid at $300 \mathrm{ppm}$ on fruit set, yield and fruit quality of Khadrawi date palm cultivar. Anyhow, bunches were sprayed at three times ( 3 hours before pollination then 4 and 8 weeks after pollination). The present results indicated that spraying date palm bunches with moringa extract or garlic extract recorded the highest initial fruit set in the first and second seasons, respectively. As well as, moringa extract gave the highest fruit retention and yield in both seasons. In addition, all treatments improved some fruit physical characteristics i.e. fruit weight, flesh weight, fruit volume and fruit length compared to the control treatment in the two studied seasons. Also, results showed that moringa extract or ascorbic acid increased TSS\%, total sugars \% and reducing sugars \% in both seasons compared to the control. Meanwhile, the lowest fibers \% was obtained by garlic extract in the two seasons. Also, all treatments had no significant effect on total acidity \% and tannins content in both seasons.

\section{INTRODUCTION}

Date palm (Phoenix dactylifera L.) belongs to the family Arecaceae and it is considered the tree of life in the desert, because it tolerates high temperatures, drought and salinity more than many other fruit crops (Lunde, 1978). Date Palm is the most successful and commercially important crop in Egypt. Numbers of date palm trees in Egypt are about 12,827, 235 trees producing about 1,465,030 tons/year, (Ministry of Agriculture and Land Reclamation, 2015). Khadrawi date palm is one of the commercial cultivars that have greenish amber fruits on ripening, slightly tolerant to humid conditions than many other varieties. As well as, fruits are consumed at rutab stage but the fruit set and productivity is low (Hussein, 2011). Nowadays, the modern trend in the field of agriculture to use of natural materials such as plant extracts or antioxidants that improve productivity and fruit quality for reducing the use of chemical materials that have harmful effects on humans and the environment.

In this respect, moringa (Moringa oleifera L.) leaves extract contains significant quantities of calcium, potassium, and cytokinin in the form of zeatin, antioxidants, $\beta$-carotene, proteins and ascorbates (Makkar et al 2007). In addition, spraying moringa extract on Hollywood plum trees (Mahmoud et al 2017) and on tomato (Muhamman et al 2013) led to increase its productivity. Garlic extract (Allium sativum, L) contains many vitamins (B1, C, A, Flavonoids), minerals ( $\mathrm{P}, \mathrm{K}, \mathrm{S}$, $\mathrm{Ca}, \mathrm{Mg}, \mathrm{Mn}, \mathrm{Fe})$, antioxidant, amino acids, so many chemical compounds, it includes volatile oil with sulfur and enzymes. Spraying garlic extract improved yield and fruit quality of Canino apricot trees (Abd El-Rzek et al 2011), on Keitte mango trees (Faissal et al 2014) and on Fagri Kalan mango trees (El-Sharony et al 2015). Ascorbic acid is an important primary metabolite in plants that functions as an antioxidant, an enzyme cofactor and a cell signaling modulator in a wide ar- 
ray of crucial physiological processes, stress tolerance, photo-protection, cell division and growth (Smirnoff and Wheeler, 2000 and Barth et al 2006). It has synergistic effect on improving growth, flowering, yield and quality of fruit crops (Ahmed et al 1997 and Maksoud et al 2009).

The main objective of the present study is to investigate the effect of spraying with moringa extract, garlic extract, and ascorbic acid on fruit set, yield and fruit quality of "Khadrawi" date palm cultivar.

\section{MATERIALS AND METHODS}

This study was carried out during two successive seasons 2015 and 2016 at the Agricultural Research Center Experimental Station, El-Kanater El-Khairia, Kalubia Governorate, Egypt on "Khadrawi" date palm cultivar. Twelve palm trees about 70 years old, grown in a clay soil at $4 \times 6 \mathrm{~m}$ under flood irrigation system were selected uniform of nearly equal size and growth vigor and were subjected to the same horticultural practices. Hand pollination was used by inserting five fresh male strands into the center of female spathe using the same source of pollens in the two seasons to avoid the effect of metaxenia. The inflorescences were wrapped with bags to prevent natural contamination, then removed out after three weeks. The leaf/bunch ratio was maintained at 7:1 for all treatments. The number of spathes per palm was adjusted at seven bunches by removing earliest, latest and smallest inflorescence for each palm.

\section{Preparation of aqueous moringa and garlic ex-} tracts

- Moringa (Moringa oleifera L.) leaves powder $(50 \mathrm{~g})$ were added to $200 \mathrm{ml}$ of distilled water. The mixture was kept for 12 hours. The extract was filtered using whatman filter paper No.1. (Dahiru et al 2006). Then $3 \%$ Concentration (30 $\mathrm{ml} /$ liter) was used for the spraying.

- Mature Chinese garlic cloves (Allium sativum, L.) one $\mathrm{Kg}$ were blended in one liter of distilled water then mixed and filtered (El-Desouky et al 1990). Then $3 \%$ concentration (30ml / liter) was used for the spraying.

\section{The four treatments were as follows}

1-Spraying with moringa extract at 3\%.

2- Spraying with garlic extract at $3 \%$.

3- Spraying with ascorbic acid at 300ppm.
4- Control (spraying with water only).

All trees of each treatment were sprayed three times ( 3 hours. before pollination then 4 and 8 weeks after pollination). Bunches were sprayed using a small hand sprayer until run-off.

\section{The following determinations were carried out}

Fruit Set and Fruit Retention: Fruit set and fruit retention percentages were calculated one month after pollination and at harvested time (Rutab stage). Ten female strands per bunch were randomly selected from each replicate. The number of set fruits were recorded and then fruit set percentage and fruit retention were calculated as the following equations:

Fruit set $(\%)=[$ Number of fruits setting on the strand / Total number of flower per strand] $\times 100$

Fruit retention (\%) $=[$ Number of retained fruits $/$

(No. of retained fruit + No. of flower scars)] $\times 100$

Yield: bunches of each palm were harvested at ripening (Rutab stage, 170 days from pollination) and weighed to determine the yield $\mathrm{Kg} / \mathrm{palm}$.

\section{Fruit physical properties}

Fruit physical properties were determined at Rutab stage as follows:-

Samples of 10 fruits were taken randomly from each bunch to determine Fruit weight $(\mathrm{g})$, flesh weight $(\mathrm{g})$, seed weight $(\mathrm{g})$ and flesh \%, fruit volume $\left(\mathrm{cm}^{3}\right)$, fruit dimensions (fruit length and diameter in $\mathrm{cm}$ ), then fruit shape index (length / diameter) were calculated.

Fruit chemical Properties: Fruit chemical properties were determined at Rutab stage as follows:-

Total soluble solids (TSS\%): total soluble solids of date fruit juice were measured using a hand refractometer according to (A.O.A.C. 1995).

Total sugars and reducing sugars \%: total sugars and reducing sugars were determined as fresh weight according to the method of Lane and Eynon as described in the (A.O.A.C. 1995).

Non reducing sugars \%: non reducing sugars were calculated by the difference between total and reducing sugars. 
Total acidity, crude fibers \% (CF) and moisture $\%$ were determined according to (A.O.A.C., 1995). Tannins content $(\mu \mathrm{g} / \mathrm{g})$ were determined according to (Hagerman and Butler, 1978).

\section{Statistical Analyses}

The experiment was designed as a randomized complete block design where each treatment was replicated three times with one palm per replicate. The obtained data were subjected to analysis of variance (ANOVA) according to (Snedecor and Cochran, 1980). The least significant ranges (LSR) were used to compare between means of treatments according to (Duncan, 1955) at probability of $5 \%$.

\section{RESULTS AND DISCUSSION}

\section{Fruit set and fruit retention $\%$}

Results in Table (1) shows that moringa and garlic extracts treatments significantly increased fruit set compared to ascorbic acid and control in the two seasons. The highest results concerning fruit set\% were obtained by spraying moringa extract $(62.21$ and $67.74 \%$ in in first and second season, respectively), and garlic extract (57.64 and
$67.19 \%$ in both seasons). On the other hand, ascorbic acid and control treatments gave the lowest values in the two seasons.

Concerning fruit retention\%, moringa extract recorded the highest value of fruit retention $\%$ in the first season compared to all treatments. In the second season, Moreover, moringa extract and garlic extract gave the best result compared to ascorbic and control treatments which gave the lowest values.

In this respect, Mahmoud et al (2017) reported that spraying moringa leaf aqueous extract at $4 \%, 5 \%$ and $6 \%$ on Hollywood plum trees (Prunus salicina L.) at three times (full bloom stage, fruit setting stage and two weeks after fruit setting stage) increased fruit set percentage and decreased fruit drop \% compared to the control treatment. Also, spraying of moringa leaves extract on pea plants (Sanjay and Pankaj, 2013) and on Tomato (Bashir et al 2014) increased fruit set\% compared to control treatment.

The increase in fruit set it may be due to the the content of moringa extract from proteins, vitamins such as (A, B1, B2, B3, C and E, $\beta$ ), minerals such as (potassium, calcium, magnesium, phosphorus and iron), gibberellins and cytokinins which regulate internal mechanism for controlling fruit set (Talon and Zeevaart, 1992).

Table 1. Effect of spraying with moringa extract, garlic extract and ascorbic acid on fruit set $\%$ and fruit retention \% of Khadrawi date palm cultivar during 2015 \& 2016 experimental seasons

\begin{tabular}{|l|c|c|c|c|}
\hline \multirow{2}{*}{\multicolumn{1}{|c|}{ Treatments }} & \multicolumn{2}{|c|}{ Fruit set \% } & \multicolumn{2}{c|}{ Fruit retention \% } \\
\cline { 2 - 5 } & 2015 Season & 2016 Season & 2015 Season & 2016 Season \\
\hline Moringa extract 3\% & $62.21 \mathrm{a}$ & $67.74 \mathrm{a}$ & $39.72 \mathrm{a}$ & $45.18 \mathrm{a}$ \\
Garlic extract 3\% & $57.64 \mathrm{ab}$ & $67.19 \mathrm{a}$ & $33.65 \mathrm{~b}$ & $45.91 \mathrm{a}$ \\
Ascorbic acid 300ppm & $55.76 \mathrm{~b}$ & $61.34 \mathrm{~b}$ & $34.03 \mathrm{~b}$ & $39.57 \mathrm{~b}$ \\
Water only (Control) & $54.74 \mathrm{~b}$ & $60.98 \mathrm{~b}$ & $31.27 \mathrm{~b}$ & $38.4 \mathrm{~b}$ \\
\hline
\end{tabular}

Means in each column with similar letter(s) are not significantly different at $5 \%$ level.

\section{Bunch weight and yield per palm}

Results in Table (2) indicated that moringa extract $3 \%$, garlic extract $3 \%$ and ascorbic acid at $300 \mathrm{ppm}$ increased bunch weight and yield/palm as compared to the control in the first season. Also, garlic extract and moringa extract treatments gave the highest bunch weight and yield/palm compared to ascorbic acid and control in the second season. Moreover, there are no significant differences between moringa extract, garlic extract and ascorbic acid on bunch weight and yield per palm in the first season. On the other hand, ascorbic acid in the second season and control treatment in the two seasons gave the lowest bunch weight and yield per palm.

These results are in harmony with those obtained by Mahmoud et al (2017) who reported that spraying of moringa leaf aqueous extract at $4 \%$, $5 \%$ and $6 \%$ on Hollywood plum trees increased yield compared to control treatment. Also, Muhamman et al (2013) showed that spraying of 
moringa aqueous extract $3 \%$ gave the highest yield of tomato compared to all treatments. Moreover, El-Sharony et al (2015) cleared that spraying mango trees cv. Fagri Kalan with garlic extract at $5 \%$ increased significantly yield as compared to the control. Also, spraying garlic extract on Keitte mango (Faissal et al 2014), on Canino Apricot (Abd El-Rzek et al 2011) and on Le Conte pear (Abd El-Rzek et al 2013) improved yield of those crops.

Table 2. Effect of spraying with moringa extract, garlic extract and ascorbic acid on bunch weight and yield/palm of Khadrawi date palm cultivar at rutab stage during 2015 \& 2016 experimental seasons

\begin{tabular}{|l|c|c|c|c|}
\hline \multirow{2}{*}{ Treatments } & \multicolumn{2}{|c|}{ Bunch weight (kg) } & \multicolumn{2}{c|}{ Yield /palm (kg) } \\
\cline { 2 - 5 } & 2015 Season & 2016 Season & 2015 Season & 2016 Season \\
\hline Moringa extract 3\% & $11.23 \mathrm{a}$ & $11.01 \mathrm{a}$ & $78.61 \mathrm{a}$ & $77.07 \mathrm{a}$ \\
Garlic extract 3\% & $10.78 \mathrm{ab}$ & $12.01 \mathrm{a}$ & $75.46 \mathrm{ab}$ & $84.07 \mathrm{a}$ \\
Ascorbic acid 300ppm & $10.49 \mathrm{ab}$ & $9.67 \mathrm{~b}$ & $73.43 \mathrm{ab}$ & $67.69 \mathrm{~b}$ \\
Water only (Control) & $9.81 \mathrm{~b}$ & $9.24 \mathrm{~b}$ & $68.67 \mathrm{~b}$ & $64.68 \mathrm{~b}$ \\
\hline
\end{tabular}

Means in each column with similar letter(s) are not significantly different at $5 \%$ level

\section{Fruit physical Properties}

\section{- Fruit weight:}

Results in Table (3) showed that the highest fruit weight in the first season was obtained when the spathes were sprayed with ascorbic acid $(13.99 \mathrm{~g})$ and garlic extract $(13.96 \mathrm{~g})$ followed by spraying with moringa extract $(13.50 \mathrm{~g})$, without significant differences among them. While, the lowest fruit weight was obtained by control treatment $(12.80 \mathrm{~g})$. Meanwhile, all treatments in the second season significantly increased fruit weight compared to control.

\section{- Flesh weight}

Results in Table (3) showed that spraying with ascorbic acid, garlic and moringa extracts gave the highest flesh weight without significant differences among them during two seasons of study while, the lowest flesh weight was obtained by control treatment in both seasons.

\section{- Seed weight}

Results in Table (3) indicated that spraying with garlic extract gave the lowest seed weight $(1.19 \& 1.07 \mathrm{~g})$ in both seasons, While, moringa extract gave the highest value $(1.28 \& 1.21 \mathrm{~g})$ in the first and second seasons, respectively.

\section{- Flesh percentage}

Results obtained that spraying with garlic extract and ascorbic acid at 300 ppm gave the highest flesh\% (91.46\% and $91.23 \%$, respectively) compared to moringa extract and control which recorded the lowest values $(90.47 \%$ and $90.43 \%$, respectively) in the first season. In addition, all treatments acid gave the highest flesh\% compared to control which recorded the lowest value $(90.20 \%)$ in the second season.

These results are in agreement with the results obtained by Abd El-Rzek et al (2011) on Canino' apricot and Faissal et al (2014) on Keitte mango they found that spraying with garlic extract increased fruit weight, flesh weight, fruit pulp \% and decreased seed weight. Also, spraying with moringa extract on 'Kinnow' mandarin increased fruit weight and pulp weight (Nasira et al 2016). In addition, Ibrahim et al (2013) reported that spraying of ascorbic acid on Zaghlol date palm increased fruit weight and pulp weight.

\section{- Fruit volume}

Results in Table (4) showed that all spraying treatments significantly increased fruit volume than control in the two seasons of study. On the other hand, there are no significant differences between moringa extract, garlic extract and ascorbic acid in the first season. Also, spraying with moringa extract and ascorbic acid gave the highest fruit volume, followed by garlic extract. While the lowest fruit value was obtained by control in the second season. 
Table 3. Effect of spraying with moringa extract, garlic extract and ascorbic acid on fruit weight, flesh weight, seed weight and flesh percentage of Khadrawi date palm fruit at Rutab stage during 2015 \& 2016 experimental seasons

\begin{tabular}{|l|c|c|c|c|}
\hline \multirow{2}{*}{ Treatments } & \multicolumn{4}{|c|}{ 2015 season } \\
\cline { 2 - 5 } & Fruit weight (g) & Flesh weight (g) & Seed weight (g) & Flesh \% \\
\hline Moringa extract 3\% & $13.50 \mathrm{ab}$ & $12.22 \mathrm{ab}$ & $1.28 \mathrm{a}$ & $90.47 \mathrm{~b}$ \\
Garlic extract 3\% & $13.96 \mathrm{a}$ & $12.77 \mathrm{a}$ & $1.19 \mathrm{~b}$ & $91.46 \mathrm{a}$ \\
Ascorbic acid 300ppm & $13.99 \mathrm{a}$ & $12.76 \mathrm{a}$ & $1.23 \mathrm{ab}$ & $91.23 \mathrm{ab}$ \\
Water only (Control) & $12.80 \mathrm{~b}$ & $11.57 \mathrm{~b}$ & $1.22 \mathrm{ab}$ & $90.43 \mathrm{~b}$ \\
\hline \multicolumn{5}{|c|}{ Treatments } \\
\multicolumn{5}{|c|}{ 2016 season } \\
\hline Moringa extract 3\% & $13.16 \mathrm{a}$ & $11.95 \mathrm{a}$ & $1.21 \mathrm{a}$ & $90.78 \mathrm{ab}$ \\
Garlic extract 3\% & $12.98 \mathrm{a}$ & $11.90 \mathrm{a}$ & $1.07 \mathrm{c}$ & $91.70 \mathrm{a}$ \\
Ascorbic acid 300ppm & $13.47 \mathrm{a}$ & $12.28 \mathrm{a}$ & $1.19 \mathrm{ab}$ & $91.16 \mathrm{ab}$ \\
Water only (Control) & $11.05 \mathrm{~b}$ & $9.97 \mathrm{~b}$ & $1.08 \mathrm{bc}$ & $90.20 \mathrm{~b}$ \\
\hline
\end{tabular}

Means in each column with similar letter(s) are not significantly different at $5 \%$ level

Table 4. Effect of spraying with moringa extract, garlic extract and ascorbic acid on fruit volume, fruit length, fruit diameter and fruit shape index of Khadrawi date palm fruit at rutab stage during 2015 \& 2016 experimental seasons

\begin{tabular}{|l|c|c|c|c|}
\hline \multirow{2}{*}{\multicolumn{1}{|c|}{ Treatments }} & \multicolumn{4}{|c|}{ 2015 season } \\
\cline { 2 - 5 } & $\begin{array}{c}\text { Fruit volume } \\
\text { (cm3) }\end{array}$ & $\begin{array}{c}\text { Fruit length } \\
\text { (cm) " L " }\end{array}$ & $\begin{array}{c}\text { Fruit diameter } \\
\text { (cm) " d " }\end{array}$ & $\begin{array}{c}\text { Fruit shape } \\
\text { index (L/d) }\end{array}$ \\
\hline Moringa extract 3\% & $12.10 \mathrm{a}$ & $3.65 \mathrm{ab}$ & $2.31 \mathrm{~b}$ & $1.58 \mathrm{a}$ \\
Garlic extract 3\% & $12.47 \mathrm{a}$ & $3.75 \mathrm{a}$ & $2.34 \mathrm{ab}$ & $1.61 \mathrm{a}$ \\
Ascorbic acid 300ppm & $12.37 \mathrm{a}$ & $3.81 \mathrm{a}$ & $2.44 \mathrm{a}$ & $1.56 \mathrm{a}$ \\
Water only (Control) & $11.10 \mathrm{~b}$ & $3.54 \mathrm{~b}$ & $2.29 \mathrm{~b}$ & $1.55 \mathrm{a}$ \\
\hline \multicolumn{1}{|c|}{ Treatments } & \multicolumn{5}{|c|}{$\mathbf{2 0 1 6}$ season } \\
\hline Moringa extract 3\% & $12.33 \mathrm{a}$ & $3.78 \mathrm{a}$ & $2.42 \mathrm{a}$ & $1.56 \mathrm{a}$ \\
Garlic extract 3\% & $11.21 \mathrm{~b}$ & $3.63 \mathrm{a}$ & $2.33 \mathrm{ab}$ & $1.56 \mathrm{a}$ \\
Ascorbic acid 300ppm & $12.15 \mathrm{a}$ & $3.73 \mathrm{a}$ & $2.40 \mathrm{a}$ & $1.55 \mathrm{a}$ \\
Water only (Control) & $10.10 \mathrm{c}$ & $3.38 \mathrm{~b}$ & $2.28 \mathrm{~b}$ & $1.48 \mathrm{a}$ \\
\hline
\end{tabular}

Means in each column with similar letter(s) are not significantly different at $5 \%$ level.

\section{- Fruit length}

Results in Table (4) showed that spraying with ascorbic acid, garlic extract or moringa extract significantly increased fruit length than control treatment in both seasons without significant differences among them. Meanwhile, the lowest fruit length was obtained by control treatment during the two seasons of study.

\section{- Fruit diameter}

In this concern, results in Table (4) indicated that spraying with ascorbic acid significantly increased fruit diameter compared to moringa extract and control in the first season. Also, spraying with moringa and garlic extracts or ascorbic acid significantly increased fruit diameter comparing to control in the second season.

\section{- Fruit shape index}

Results in Table (4) showed that there was insignificant effect between all treatments and control on fruit shape index in both seasons of study.

These results in harmony with those obtained by Ibrahim et al (2013) on Zaghlol date palm and ElSayed et al (2014) on Manzanillo olive trees, they found that spraying with ascorbic acid increased fruit volume, fruit length and fruit diameter. Also, 
spraying with moringa leaf aqueous extract on Hollywood plum (Prunus salicina L.) increased fruit length (Mahmoud et al 2017). In addition, spraying with garlic extract on Keitte mango increased fruit volume and fruit length (Faissal et al 2014).

\section{Fruit chemical properties}

\section{- Total Soluble Solids \%}

In this concern, results in Table (5) indicated that all spraying treatments increased significantly TSS \% compared to control in the first season. But there were insignificance differences between all spraying treatments in this season. On the other hand, ascorbic acid or moringa extract gave the highest significant TSS\% compared to garlic extract and control in the second season.

\section{- Total sugars \%}

Results in Table (5) showed that all treatments had significant effect on total sugars \% compared to control which recorded the lowest value in the first season. Meanwhile, the highest value was obtained by spraying bunches with moringa extract $(38.05 \%)$ followed by ascorbic acid $(37.41 \%)$ then garlic extract $(36.48 \%)$ as compared to control which gave the lowest total sugars content $(35.05 \%)$ in the first season. In addition, moringa extract or ascorbic acid increased significantly TSS\% compared to garlic extract and control in the second season.

\section{- Reducing sugars \%}

In this regard results in Table (5) showed that spraying bunches with moringa extract significantly increased reducing sugars \% compared to all treatments in the first season. In another meaning, moringa extract gave the highest value followed by ascorbic acid while, the least value was obtained by control in the first season. Meanwhile, moringa extract or ascorbic acid significantly increased reducing sugars \% compared to garlic extract and control in the second season.

\section{- Non reducing sugars}

As shown from Table (5) that, there are no significant differences between all spraying treatments and control during the two seasons of study. These results are in agreement with the results obtained by Mahmoud et al (2017) they reported that spraying with moringa leaf aqueous extract on Hollywood plum increased T.S.S\%, total sugar \% and reducing sugar\% compared to control. Also, Ibrahim et al (2013) found that spraying of ascorbic acid at 500 to 2000 on Zaghlol date palm increased T.S.S\%, total sugar\% and reducing sugar\% compared to control.

\section{- Total acidity \%}

Concerning the fruit juice total acidity \% results in Table (6) showed that, no significant differences between all spraying treatments and control during the two seasons of study.

\section{- Tannins content}

It is quite clear as shown from tabulated data in Table (6) that the response of tannins content in Khadrawi date palm cv. to the different treatments followed to great extent the same trend previously detected with total acidity \% during both seasons of study.

\section{- Fibers \%}

Results in Table (6) showed that, spraying bunches with garlic extract gave the lowest fibers $\%$ compared to other spraying treatments and control in the two seasons. Also, there are no significant differences between moringa extract, ascorbic acid or control in the first season. Meanwhile, all spraying treatments significantly decreased fibers\% compared to control in the second season. anyhow, these results are in harmony with those obtained by Faissal et al (2014) they found that spraying garlic oil extract $0.1 \%$ at three times on Keitte mango cv. decreased total fiber \% compared to control treatment.

\section{- Fruit moisture \%}

In this regard results in Table (6) indicated that all treatments had no significant effect on fruit moisture \% as compared to control in the first season. Meanwhile, moringa extract or ascorbic acid decreased significantly moisture\% compared to garlic extract and control in the second season. In this respect, spraying of moringa leaves extract on Pea plans (Sanjay and Pankaj, 2013) and on rocket plants (Abdalla, 2013) increased dry weight as compared to control. 
Table 5. Effect of spraying moringa extract, garlic extract and ascorbic acid on total soluble solids \%, total sugars $\%$, reducing sugars $\%$ and non-reducing sugars $\%$ of Khadrawi date palm fruit at rutab stage during 2015 \& 2016 experimental seasons

\begin{tabular}{|l|c|c|c|c|}
\hline \multirow{2}{*}{ Treatments } & \multicolumn{4}{|c|}{ 2015 season } \\
\cline { 2 - 5 } & TSS\% & Total sugars\% & Reducing sugars\% & $\begin{array}{c}\text { Non reducing } \\
\text { sugars\% }\end{array}$ \\
\hline Moringa extract 3\% & $45.03 \mathrm{a}$ & $38.05 \mathrm{a}$ & $35.05 \mathrm{a}$ & $3.01 \mathrm{a}$ \\
Garlic extract 3\% & $44.50 \mathrm{a}$ & $36.48 \mathrm{~b}$ & $32.06 \mathrm{~b}$ & $4.42 \mathrm{a}$ \\
Ascorbic acid 300ppm & $45.20 \mathrm{a}$ & $37.41 \mathrm{ab}$ & $33.18 \mathrm{~b}$ & $4.23 \mathrm{a}$ \\
Water only (Control) & $41.33 \mathrm{~b}$ & $35.05 \mathrm{c}$ & $31.91 \mathrm{~b}$ & $3.14 \mathrm{a}$ \\
\hline \multicolumn{1}{|c|}{ Treatments } & \multicolumn{3}{|c|}{$\mathbf{2 0 1 6}$ season } & $3.55 \mathrm{a}$ \\
\hline Moringa extract 3\% & $47.57 \mathrm{a}$ & $38.63 \mathrm{a}$ & $35.08 \mathrm{a}$ & $3.95 \mathrm{a}$ \\
Garlic extract 3\% & $45.02 \mathrm{~b}$ & $35.53 \mathrm{~b}$ & $31.58 \mathrm{~b}$ & $3.87 \mathrm{a}$ \\
Ascorbic acid 300ppm & $48.05 \mathrm{a}$ & $38.46 \mathrm{a}$ & $34.59 \mathrm{a}$ & $3.28 \mathrm{a}$ \\
Water only (Control) & $44.18 \mathrm{~b}$ & $34.68 \mathrm{~b}$ & $31.40 \mathrm{~b}$ & \\
\hline
\end{tabular}

Means in each column with similar letter(s) are not significantly different at $5 \%$ level

Table 6. Effect of spraying moringa extract, garlic extract and ascorbic acid on total acidity\%, tannins $(\mu \mathrm{g} / \mathrm{g})$, fibers $\%$ and moisture $\%$ of Khadrawi date palm fruit at rutab stage during 2015 \& 2016 experimental seasons

\begin{tabular}{|l|c|c|c|c|}
\hline \multirow{2}{*}{\multicolumn{1}{|c|}{ Treatments }} & \multicolumn{4}{|c|}{2015 season } \\
\cline { 2 - 5 } & Total acidity\% & Tannins $(\boldsymbol{\mu g} / \mathbf{g})$ & Fibers\% & Moisture\% \\
\hline Moringa extract 3\% & $0.063 \mathrm{a}$ & $0.023 \mathrm{a}$ & $1.54 \mathrm{a}$ & $48.48 \mathrm{a}$ \\
Garlic extract 3\% & $0.069 \mathrm{a}$ & $0.020 \mathrm{a}$ & $1.34 \mathrm{~b}$ & $52.64 \mathrm{a}$ \\
Ascorbic acid 300ppm & $0.069 \mathrm{a}$ & $0.030 \mathrm{a}$ & $1.58 \mathrm{a}$ & $49.32 \mathrm{a}$ \\
Water only (Control) & $0.073 \mathrm{a}$ & $0.022 \mathrm{a}$ & $1.62 \mathrm{a}$ & $51.41 \mathrm{a}$ \\
\hline \multicolumn{4}{|c|}{ Treatments } & \multicolumn{4}{|c}{} \\
\hline Moringa extract 3\% & $0.067 \mathrm{a}$ & $0.033 \mathrm{a}$ & $1.51 \mathrm{~b}$ & $42.11 \mathrm{~b}$ \\
Garlic extract 3\% & $0.059 \mathrm{a}$ & $0.026 \mathrm{a}$ & $1.29 \mathrm{~d}$ & $44.18 \mathrm{a}$ \\
Ascorbic acid 300ppm & $0.066 \mathrm{a}$ & $0.029 \mathrm{a}$ & $1.41 \mathrm{c}$ & $42.63 \mathrm{~b}$ \\
Water only (Control) & $0.074 \mathrm{a}$ & $0.028 \mathrm{a}$ & $1.64 \mathrm{a}$ & $44.17 \mathrm{a}$ \\
\hline
\end{tabular}

Means in each column with similar letter(s) are not significantly different at $5 \%$ level

In this phare, from Tables $(5,6)$ we can observe that, TSS, total sugars and reducing sugars were increased. While, non-reducing sugars, total acidity, tannins and moisture content were decrease with reach the fruit to the Rutab stage, this led to costume freshly fruit with good eating quality.

Generally results cleared that spraying of moringa extract $3 \%$ for three times (3 hours before pollination, one month after pollination and two month after pollination) gave the highest fruit set $\%$, fruit retention, yield, fruit weight, fruit volume,
TSS\%, total sugar and reducing sugar of Khadrawi date palm cultivar in both seasons, respectively.

\section{REFERENCE}

Abd El-Rzek, E., El-Migeed, M.A. and AbdelHamid, N. 2011. Effect of spraying garlic extract and olive oil on flowering behavior, yield and fruit quality of 'Canino'apricot trees. American-Eurasian J. of Agric. and Environmental Sci., 11(6), 776-781. 
Abd El-Rzek, E., El-Migeed, M.A. and AbdelHamid, N. 2013. Response of 'Le Conte'Pear Trees to Garlic Extract and GA as Budbreak Dormancy Agents. Middle-East J. of Scientific Res., 14(11), 1407-1413.

Abdalla, M.M. 2013. The potential of Moringa oleifera extract as a biostimulant in enhancing the growth, biochemical and hormonal contents in rocket (Eruca vesicaria subsp. sativa) plants. International J. of Plant Physiology and Biochemistry, 5(3), 42-49.

Ahmed, F.F., Akl, A.M., Gobara, A.A. and Mansour, A.E. 1997. Yield and quality of Anna apple trees (Malus domestica) in response to foliar application of ascorbine and citrine fertilizer. Egypt. J. Hort. 25(2), 120-139.

Association of Official Agricultural Chemists. 1995. Official Methods of Analysis of A.O.A.C., pub. by A.O.A.C. Chapter (4) 18 p.; (37) 10 p.; (44) pp. 8-9 International suite 4002200 Wilson Boulevard Arlington, Virginia, USA.

Barth, C., De Tullio, M. and Conklin, P.L. 2006. The role of ascorbic acid in the control of flowering time and the onset of senescence. J. of Experimental Botany, 57(8), 1657-1665.

Bashir, K.A., Bawa, J.A. and Mohammed, I. 2014. Efficacy of leaf extract of drumstick tree (Moringa Oleifera Lam.) on the growth of local Tomato (Lycopersicon esculentum). J. Pharmacy and Bio. Sci., 9(4), 74-79.

Dahiru, D., Onubiyi, J.A. and Umaru, H.A. 2006. Phytochemical screening and antiulcerogenic effect of Moringa oleifera aqueous leaf extract. African J. of Traditional, Complementary and Alternative medicines, 3(3), 70-75.

Duncan, D.B. 1955. Multiple range and multiple $F$ tests. Biometrics, 11(1), 1-42.

El-Desouky, S.A., Wanas, A.L.A. and Khedr, Z.M.A. 1990. Utilization of some natural plant extracts (of garlic \& yeast) as seed-soaked materials to squash (cucubita pepo L.). 1- Effect on growth, sex expression and fruit yield and quality. Annals of Agric. Sci. Moshtohor, 36(2), 839-854.

El-Sayed, O.M., El-Gammal, O.H.M. and Salama, A.S.M. 2014. Effect of ascorbic acid, proline and jasmonic acid foliar spraying on fruit set and yield of Manzanillo olive trees under salt stress. Scientia Hortic., 176, 32-37.

El-Sharony, T.F., El-Gioushy, S.F. and Amin, O.A. 2015. Effect of Foliar Application with Algae and Plant Extracts on Growth, Yield and Fruit Quality of Fruitful Mango Trees Cv. Fagri Kalan. J. Hortic., 2(4), 1-6.
Faissal, F.A., Kamel, M.Kh. and Ibrahim, H.I.M. 2014. The Synergistic Effects of Using 'Plant Extracts and Salicylic Acid on Yield and Fruit Quality of Keitte Mango Trees. Stem Cell, 5(2), 30-39.

Hagerman, A.E. and Butler, L.G. 1978. Protein precipitation method for the quantitative determination of tannins. J. of Agric. and Food Chemistry, 26(4), 809-812.

Hussein, J.S. 2011. Effect of spraying with Urea and NPK on production of Date Palm (Phoenix dactylifera L.) Cv. Khidrawi. J. of Basrah Res. Sci., 37 (4), 13-25.

Ibrahim, H.I.M., Ahmed, F.F., Akl, A.M.A. and Rizk, M.N.S. 2013. Improving Yield Quantitively and Qualitatively of Zaghloul Date Palms by Using some Antioxidants. Stem Cell, 4(2), 3440.

Lunde, P. 1978. A History of Dates. Saudi Aramco World, 29(2), 176-179.

Mahmoud, Th.Sh., Kassim, N.E., AbouRayya, M.S. and Abdalla, A.M. 2017. Influence of Foliar Application with Moringa (Moringa oleifera L.) Leaf Extract on Yield and Fruit Quality of Hollywood Plum Cultivar. J. Hortic. 4 (1), 1-7.

Makkar, H.P.S., Francis, G. and Becker, K. 2007. Bioactivity of phytochemicals in some lesserknown plants and their effects and potential applications in livestock and aquaculture production systems. Animal, 1(9), 1371-1391.

Maksoud, M.A., Saleh, M.A., El-Shamma, M.S. and Fouad, A.A. 2009. The beneficial effect of biofertilizers and antioxidants on olive trees under calcareous soil conditions. World J. Agric. Sci, 5(3), 350-352.

Ministry of Agriculture and Land Reclamation, Egypt 2015. Total Area, Yield and Production for Palm Dates, Economic Affairs, Stats. Sector. $352 \mathrm{p}$.

Muhamman, M.A., Auwalu, B.M., Manga, A.A. and Jibrin, J.M. 2013. Effects of Aqueous extract of Moringa (Moringa oleifera Lam.) and Nitrogen rates on some Physiological attributes and yield of Tomato. Int. J. Chem. Environ Biolo. Sci., 1(1), 2320-4087.

Nasir, M., Khan, A.S., Basra, S.A. and Malik, A.U. 2016. Foliar application of moringa leaf extract, potassium and zinc influence yield and fruit quality of 'Kinnow'mandarin. Scientia Hortic., 210, 227-235.

Sanjay, S. and Pankaj, S. 2013. Moringa oleivera leaf extract as biostimulant for increasing pea yield. Indian Forester, 139(6), 562-563. 
Smirnoff, N. and Wheeler, G.L. 2000. Ascorbic acid in plants: biosynthesis and function. Critical Reviews in Biochemistry and Molecular Biology, 35(4), 291-314.

Snedecor, G.W. and Cochran, W.G. 1980. Statistical Methods Oxford and JBH Publishing. $7^{\text {th }}$ Ed.. Washington, D.C., USA.
Talon, M. and Zeevaart, J.A. 1992. Stem elongation and changes in the levels of gibberellins in shoot tips induced by differential photoperiodic treatments in the long-day plant Silene Armeria. Planta, 188(4), 457-461. 